\title{
Effect of Dehydration Techniques over the Morpho-Physiological Characters in African Marigold (Tagetes erecta L.)
}

\author{
Aritra Sarkar*, Jayoti Majumder, Amit Lohar and Bipra Thakur \\ Department of Floriculture and Landscaping, B.C.K.V., Nadia, WB, India \\ *Corresponding author
}

\section{A B S T R A C T}

\section{Keywords \\ Tagetes erecta, Total chlorophyll, \\ Lycopene, Total phenols, RHS color \\ Article Info \\ Accepted: \\ 08 August 2018 \\ Available Online: \\ 10 September 2018}

The influence of different drying methods on biochemical properties and visual characters of African marigold (Tagetes erecta L.) cultivar "Seracole", was carried out. The petals of marigold flowers were dried by five different methods viz. sun drying, shade drying, oven drying, cabinet drying and infrared drying. The biochemical constituents were analyzed on total chlorophyll (mg.g $\left.{ }^{-1} \mathrm{f} . \mathrm{w}\right)$, lycopene (mg/100g sample) and total phenols (mg of $\mathrm{GAE} / \mathrm{g})$. Infrared dried petals exhibit a high yield of total chlorophyll $\left(\mathrm{T}_{11 ;} ; 0.120 \mathrm{mg} \cdot \mathrm{g}^{-1}\right.$ f.w) and lycopene $\left(\mathrm{T}_{10} ; 55.92 \mathrm{mg} / 100 \mathrm{~g}\right.$ sample) followed by sun drying $\left(\mathrm{T}_{0} ; 0.060 \mathrm{mg} \cdot \mathrm{g}^{-1}\right.$ f.w and $\mathrm{T}_{0 ;} 41.17 \mathrm{mg} / 100 \mathrm{~g}$ sample respectively). Highest content of total phenol was found in cabinet drying $\left(\mathrm{T}_{6} ; 56.33 \mathrm{mg}\right.$ of $\mathrm{GAE} / \mathrm{g}$ ), whereas minimum total phenol were found in Sun drying $\left(\mathrm{T}_{0 ;} 44.29 \mathrm{mg}\right.$ of $\left.\mathrm{GAE} / \mathrm{g}\right)$. There was found to be significant increase in overall infrared dried samples retained better biochemical properties than other drying methods.

\section{Introduction}

African marigold (Tagetes erecta L.) is one of most important flowers belongs to the family of Asteraceae, which grows in warm, temperate and Mediterranean region. The pharmacological activities of marigold are related to the content of several classes of secondary metabolites. New researches and reviews concerning the composition and nutritional value of edible flowers are also important and represent a sufficient reason for their consumption (Koike et al., 2015). The edible flowers reveal as pharmacological resource possessing the following properties antianxiety, anticancer, antidiabetic, antiinflammatory, anti-oxidant, diuretic, anthelmintic, immunomodulatory, antimicrobial along with its effective dosage (Rigane et al., 2013). A recent study reveals that flowers with higher total phenolics content are Antigonon leptopus, Bougainvillea glabra, Tagetes erecta, Cosmos sulphureus, Prunus mume and Sophora viciifolia with values $>100 \mathrm{mg} / \mathrm{g} \mathrm{dw}$ (Cavaiuolo et al., 2013). Many studies have reported that phenolic compounds possess other biological activities such as anti-inflammatory, antiulcer, antispasmodic, antisecretory, antiviral, antidiarrhoeal, antitumor, etc. (Carlo et al., 1999).

Drying is an important process for handling raw materials in order to prolong shelf life, as the drying process inhibits enzymatic degradation and limits microbial growth 
(Ahrne' et al., 2007). Far-infrared radiation (FIR) has been reported to be successfully applied in the drying of foods (Sandu, 1986) and agricultural products since the main components of these products have their principal absorption bands in the far-infrared region (Meeso, 2008). Unlike hot air drying, FIR generates internal heating through molecular vibration of the material, bringing about excited vibration when molecules absorb the radiation of certain wavelengths and energy (Sandu, 1986). Fresh petals contain biochemicals as well as dried petals. Keeping the fresh petals for longer period is problematic due to higher moisture content which accelerates the multiplication of fungal growth. Hence, studies were carried out to identify the most suitable drying methods for maximum recovery of biochemical properties for African marigold (T. erecta).

\section{Materials and Methods}

The experiment was conducted at Department of Floriculture and Landscaping, Faculty of Horticulture, Bidhan Chandra Krishi Viswavidyalaya, Mohanpur, Nadia, West Bengal, India in 2016 to 2017. African marigold (Tagetes erecta L.) flower specially "Seracole" variety was collected from Mondouri farm, BCKV. Besides the laboratory studies were carried out at Dept. of Floriculture and Landscaping laboratory, BCKV. Total Chlorophyll content were measured by DMSO \{Dimethyl sulfoxide, $\left.\left(\mathrm{CH}_{3}\right)_{2} \mathrm{SO}_{4}\right\}$ method and calculated using following formula.

Total Chlorophyll (mg.g ${ }^{-1}$ f.w) $=\frac{(20.07 \times 0 \mathrm{DD} 645 \mathrm{~nm})+(8.02 \times * 0 \mathrm{D} 663 \mathrm{~nm}) \times \text { volume } \times \text { dilution }}{1000 \times \text { weight of sample }}$

\section{*Optical Density}

For lycopene analysis, the dried flower sample (1.0-1.5 g powder) was extracted with $10 \mathrm{~mL}$ acetone-petroleum ether $(50 \% \mathrm{v} / \mathrm{v})$. The upper lycopene-containing organic layer was removed by means of a pipette and collected in test tube. Extraction was repeated. The extracts were combined, washed with $15 \mathrm{~mL}$ saturated aqueous sodium chloride $(\mathrm{NaCl})$ and removed the aqueous wash with a micropipette. The extract was washed with $10 \mathrm{~mL}$ of $10 \%$ aqueous potassium carbonate $\left(\mathrm{K}_{2} \mathrm{CO}_{3}\right)$ and removed the aqueous wash. The lycopene-containing organic layer was dried with a drying agent (calcium chloride). The excess solvent was allowed to evaporate at room temperature for a few minutes in the dark. The tubes containing lycopene extracts were covered with aluminium foil and stored in freezer until further analysis (Shahzad et al., 2014). The samples were read at $503 \mathrm{~nm}$ in UV-VIS spectrophotometer (VARIAN CARY®, USA) and the calculated using following formula.

$$
\begin{aligned}
& \text { Lycopene (mg/100g sample) } \\
& =3.1206 \times 0 \mathrm{D} \text { at } 503 \mathrm{~nm} \times \text { volume made up } \times \text { dilution } \times 100 \\
& 1000 \mathrm{X} \text { weight of sample }
\end{aligned}
$$

The total phenolic content (TPC) was determined using the Folin-Ciocalteu reagent according to Stintzing et al., with some modifications. Basically, $5 \mathrm{~g}$ sample was taken and extracted with $20 \mathrm{ml}$ ethanol (80\%) using homogenizer (POLYTRON® PT 1600 E). Then it was centrifuged (SIGMA $3 \mathrm{~K} 30, \mathrm{UK}$ ) at $10,000 \mathrm{rpm}$ for $15 \mathrm{~min}$ at $4^{\circ} \mathrm{C}$. The supernatant was stored at $-20^{\circ} \mathrm{C} .100 \mu \mathrm{l}$ sample was taken and the volume was made up to $3 \mathrm{ml}$ by adding $2.9 \mathrm{ml}$ distilled water in a test tube.

$0.5 \mathrm{ml}$ Folin ciocaltcu's reagent was added and after $3 \mathrm{~min}, 2 \mathrm{ml}$ of $20 \%$ sodium carbonate was added and filtered it. The test tube was then placed in boiling water for 1 min. After boiling, it was cooled and volume was increased 10 times by adding water. Then it was observed at $750 \mathrm{~nm}$ against reagent blank. The measurements were compared to a standard curve of prepared Gallic acid (GA) 
solution, and the total phenolic content was expressed as milligrams of Gallic acid equivalents (GAE) per gram of dry weight.

For Estimation of colour, the dried petals from each drier were analyzed with RHS colour chart (Royal Horticultural Society, Great Britain).

The experimental data collected from four different types of drying methods were subjected to the statistical analysis appropriate to completely randomized designs (CRD). The critical difference between the entries was at $5 \%$ level of significance.

\section{Results and Discussion}

A significant and wide variation was recorded for anti-oxidants in dried marigold petal extract of twelve treatments (Table 1). The biochemical estimation revealed that the petal extract of $\mathrm{T}_{11}$ contained highest chlorophyll $\left(0.120 \mathrm{mg} \mathrm{g}^{-1}\right.$ f.w) followed by $\mathrm{T}_{10}(0.119 \mathrm{mg}$ $\mathrm{g}^{-1}$ f.w) and $\mathrm{T}_{9}\left(0.113 \mathrm{mg} \mathrm{g}^{-1}\right.$ f.w); the lowest were exhibited by the $T_{0}\left(0.060 \mathrm{mg} \mathrm{g}^{-1}\right.$ f.w $), \mathrm{T}_{1}$ (0.061 mg g ${ }^{-1}$ f.w) and $T_{2}\left(0.061 \mathrm{mg} \mathrm{g}^{-1}\right.$ f.w). Petrova et al., (2016) reported that among the investigated flowers samples Geranium macrorrhizum L. $95 \%$ ethanol extracts were evaluated as the richest source of total chlorophylls (41.5 $\mu \mathrm{g} / \mathrm{g}$ f.w) followed by Tagetes erecta L. (23.6 $\mu \mathrm{g} / \mathrm{g}$ f.w), Calendula officinalis L. (22.5 $\mu \mathrm{g} / \mathrm{g}$ f.w) and Helianthus tuberosus L. (0.5 $\mu \mathrm{g} / \mathrm{g}$ f.w).

The distributed estimation revealed the maximum lycopene concentration was recorded in $\mathrm{T}_{10}(55.92 \mathrm{mg} / 100 \mathrm{~g}$ sample) and $\mathrm{T}_{6} \quad(55.64 \mathrm{mg} / 100 \mathrm{~g}$ sample); the lowest lycopene was exhibited by the $\mathrm{T}_{0}(41.17$ $\mathrm{mg} / 100 \mathrm{~g}$ sample). Near about similar results had been reported by Siriamornpun et al., (2012). They evaluated the sample of Tagetes erecta L. from FIR-HA drying and found highest amount lycopene $(58.7 \mathrm{mg} / 100 \mathrm{~g} \mathrm{DW})$ (Increased by $54 \%$ compared to fresh materials) followed by the HA and FD samples with concentrations of 51.2 and 48.7 $\mathrm{mg} / 100 \mathrm{~g} \mathrm{DW}$ respectively.

Table.1 Treatments of sun drying, shade drying, oven drying, cabinet drying and infrared drying

\begin{tabular}{|c|c|c|}
\hline Treatments & Types of drying & Conditions of drying \\
\hline $\mathbf{T}_{\mathbf{0}}$ & Sun drying & February $\left(30^{\circ} \mathrm{C}+70 \% \mathrm{RH}+10\right.$ days $)$ \\
\hline $\mathbf{T}_{\mathbf{1}}$ & Shade drying & February $\left(22^{\circ} \mathrm{C}+65 \% \mathrm{RH}+15\right.$ days $)$ \\
\hline $\mathbf{T}_{\mathbf{2}}$ & Shade drying & December $\left(19^{\circ} \mathrm{C}+65 \% \mathrm{RH}+15\right.$ days $)$ \\
\hline $\mathbf{T}_{\mathbf{3}}$ & Oven drying & $60^{\circ} \mathrm{C}+4$ hours $+30 \% \mathrm{RH}$ \\
\hline $\mathbf{T}_{\mathbf{4}}$ & Oven drying & $60^{\circ} \mathrm{C}+6$ hours $+30 \% \mathrm{RH}$ \\
\hline $\mathbf{T}_{\mathbf{5}}$ & Oven drying & $60^{\circ} \mathrm{C}+8$ hours $+30 \% \mathrm{RH}$ \\
\hline $\mathbf{T}_{\mathbf{6}}$ & Cabinet drying & $55^{\circ} \mathrm{C}+2$ hours $+70 \% \mathrm{RH}$ \\
\hline $\mathbf{T}_{\mathbf{7}}$ & Cabinet drying & $55^{\circ} \mathrm{C}+4$ hours $+70 \% \mathrm{RH}$ \\
\hline $\mathbf{T}_{\mathbf{8}}$ & Cabinet drying & $55^{\circ} \mathrm{C}+6$ hours $+70 \% \mathrm{RH}$ \\
\hline $\mathbf{T}_{\mathbf{9}}$ & Infrared drying & $50^{\circ} \mathrm{C}+1$ hour $+70 \% \mathrm{RH}$ \\
\hline $\mathbf{T}_{\mathbf{1 0}}$ & Infrared drying & $50^{\circ} \mathrm{C}+2$ hours $+70 \% \mathrm{RH}$ \\
\hline $\mathbf{T}_{\mathbf{1 1}}$ & Infrared drying & $50^{\circ} \mathrm{C}+3$ hours $+70 \% \mathrm{RH}$ \\
\hline
\end{tabular}


Table.2 Total chlorophyll, Lycopene and Total phenol content in Different types of drying methods

\begin{tabular}{|c|c|c|c|}
\hline Treatments & $\begin{array}{c}\text { Total Chlorophyll (mg. } \\
\left.\mathbf{g}^{-\mathbf{1}} \mathbf{f . w}\right)\end{array}$ & $\begin{array}{c}\text { Lycopene (mg/100g } \\
\text { sample) }\end{array}$ & $\begin{array}{c}\text { Total phenol (mg of } \\
\text { GAE/g) }\end{array}$ \\
\hline $\mathbf{T}_{\mathbf{0}}$ & 0.060 & 41.17 & 44.29 \\
\hline $\mathbf{T}_{\mathbf{1}}$ & 0.061 & 46.23 & 46.40 \\
\hline $\mathbf{T}_{\mathbf{2}}$ & 0.061 & 47.68 & 46.58 \\
\hline $\mathbf{T}_{\mathbf{3}}$ & 0.063 & 53.60 & 55.92 \\
\hline $\mathbf{T}_{\mathbf{4}}$ & 0.090 & 54.23 & 54.49 \\
\hline $\mathbf{T}_{\mathbf{5}}$ & 0.087 & 55.46 & 53.51 \\
\hline $\mathbf{T}_{\mathbf{6}}$ & 0.069 & 55.64 & 56.33 \\
\hline $\mathbf{T}_{\mathbf{7}}$ & 0.084 & 53.42 & 55.40 \\
\hline $\mathbf{T}_{\mathbf{8}}$ & 0.083 & 50.53 & 54.71 \\
\hline $\mathbf{T}_{\mathbf{9}}$ & 0.113 & 50.75 & 53.19 \\
\hline $\mathbf{T}_{\mathbf{1 0}}$ & 0.119 & 55.92 & 52.82 \\
\hline $\mathbf{T}_{\mathbf{1 1}}$ & 0.120 & 50.50 & 52.46 \\
\hline $\mathbf{S E m}(\mathbf{(})$ & 0.00016 & 0.523 & 0.194 \\
\hline $\mathbf{C D} \mathbf{( 5 \% )}$ & 0.00047 & 1.540 & 0.571 \\
\hline
\end{tabular}

Table.3 RHS colour chart with different dried flower samples

\begin{tabular}{|c|c|}
\hline Types of drying & RHS colour chart \\
\hline Sun dried samples & Brown orange (RSH 171B) + Orange brown (RHS 170A) \\
\hline Shade dried samples & Brown orange (RHS 171B) + Orange brown (RHS 170A) \\
\hline Oven dried samples & Brown orange (RHS 171B) + Brown orange (RHS 169C) \\
\hline Cabinet dried samples & Brown orange (RHS 171B) + Brown orange (RHS 169C) \\
\hline Infrared dried samples & Red brown (RHS 172A) + Brown orange (RHS 171B) \\
\hline
\end{tabular}

Phenols are produced in response to certain pathogen and are considered essential for the growth and reproduction of plants. In Table 2 shows that total phenol content decreased significantly in dried samples as compared to fresh samples. The cabinet drying viz. $\mathrm{T}_{6}\left(55^{\circ} \mathrm{C}\right.$ for 2 hours with $30 \% \mathrm{RH})$ gave $56.33 \mathrm{mg}$ of GAE/g (max.) followed by $\mathrm{T}_{3}(55.92 \mathrm{mg}$ of $\mathrm{GAE} / \mathrm{g})$ and $\mathrm{T}_{7}(55.40 \mathrm{mg}$ of $\mathrm{GAE} / \mathrm{g})$, whereas minimum was recorded in $\mathrm{T}_{0}(44.29 \mathrm{mg}$ of GAE/g). Ahluwalia et al., (2014) reported the total phenol content in Pusa Basanti was 109.4 $\mathrm{mg} \mathrm{GAE} / \mathrm{g}$ in fresh which decreased to $20.2 \mathrm{mg}$ $\mathrm{GAE} / \mathrm{g}$ in vacuum dried, $16.63 \mathrm{mg} \mathrm{GAE} / \mathrm{g}$ in cabinet dried $45.8 \mathrm{mg}$ GAE/g in fan dried, 47.4 $\mathrm{mg}$ GAE/g in solar dried sample. In Pusa
Narangi the value for total phenol content for fresh sample was $112.2 \mathrm{mg}$ GAE/g which decreased to $71.6 \mathrm{mg} \mathrm{GAE} / \mathrm{g}$ for vacuum dried, $60.8 \mathrm{mg} \mathrm{GAE} / \mathrm{g}$ for cabinet dried $46.4 \mathrm{mg}$ GAE/g for fan dried, $45 \mathrm{mg}$ GAE/g for solar dried sample.

The results for colour parameters in different dried petals were presented in Table 3 . From the observation results, brown orange (RSH 171B) and orange brown (RHS 170A) colour were found in sun dried samples. The shade drying samples also gave brown orange (RSH 171B) and orange brown (RHS 170A) colour. The oven and cabinet dried samples were closely related in terms of colour (brown orange; RHS 
171B and brown orange; RHS 169C). Whereas infrared dried samples had shown red brown (RHS 172A) and brown orange (RHS 171B) colour.

The results revealed that the infrared drying gave the best results from the preservation of quality with respect to chemical and functional constituents' point of view.

\section{References}

Ahluwalia, P., Kaur, A. and Dhillon, G. K. (2014). Effect of Different Drying Methods on Chemical and Functional Properties of Marigold Petals. International Journal of Food and Nutritional Sciences, 3: 54-59.

Ahrne, L. M., Pereira, N. R., Staack, N., and Floberg, P. (2007). Microwave convective drying of plant foods at constant and variable microwave power. Drying Technology, 25(7), 1149-1153.

Carlo, G.D.N., Mascolo, A. A. and Izzo, F. (1999). Flavonoids: old and new aspects of a class of natural therapeutic drugs, Life Sciences, 65:337-353.

Cavaiuolo, M., Cocetta, G. and Ferrante, A. (2013). The Antioxidants Changes in Ornamental Flowers during Development and Senescence. Antioxidants. 2:132-155.

Koike, A., Barreira, J. C. M., Barros, L., Santos-Buelga, C., Villavicencio, A. L. C. H. and Ferreira, I. C. F. R. (2015). Edible flowers of Viola tricolor L. as a new functional food: Antioxidant activity, individual phenolics and effects of gamma and electron-beam irradiation. Food Chemistry. 179: 6-14.

Meeso, N., Nathakaranakule, A., Madhiyanon, T., and Soponronnarit, S. (2008).
Different strategies of far-infrared radiation application in paddy drying. International Journal of Food Engineering, 4:1-30.

Petrova, I., Petkova, N. and Ivanov, I. (2016). Five Edible Flowers - Valuable Source of Antioxidants in Human Nutrition. International Journal of Pharmacognosy and Phytochemical Research, 8(4): 604610.

Rigane, G., Ben, Younes. S., Ghazghazi, H. and Salem, R. B. (2013). Investigation into the biological activities and chemical composition of Calendula officinalis $\mathrm{L}$. growing in Tunisia. International Food Research Journal. 20(6): 3001-3007.

Sandu, C. (1986). Infrared radiative drying in food engineering: A process analysis. Biotechnology Progress, 2:109-119.

Shahzad, T., Ahmad, I., Choudhry, S., Saeed, M. K. and Khan, M. N., (2014). Dpph free radical scavenging activity of tomato, cherry tomato and watermelon: lycopene extraction, purification and quantification, International Journal of Pharmacy and Pharmaceutical Sciences, Vol. 6.

Siriamornpun, S., Kaisoon, O. and Meeso, N. (2012). Changes in colour, antioxidant activities and carotenoids (lycopene, $\beta$ carotene, lutein) of marigold flower (Tagetes erecta L.) resulting from different drying processes. Journal of Functional Foods, 4: 757-766.

Stintzing, F. C., Herbach, K. M., Mosshammer, M. R., Carle, R., Weiguang, Y., Sellappan, S., Akoh, C. C., Bunch, R. and Felker, P. (2005). Color, Betalain Pattern, and Antioxidant Properties of Cactus Pear (Opuntia spp.) Clones. J. Agric. Food Chem., 53: 442-451.

\section{How to cite this article:}

Aritra Sarkar, Jayoti Majumder, Amit Lohar and Bipra Thakur. 2018. Effect of Dehydration Techniques over the Morpho-Physiological Characters in African Marigold (Tagetes erecta L.). Int.J.Curr.Microbiol.App.Sci. 7(09): 1240-1244. doi: https://doi.org/10.20546/ijcmas.2018.709.148 